\title{
Reference to Great Issues ${ }^{1}$
}

\author{
Mr. Laing is director, Public Affairs \\ Laboratory, and assistant librarian, Dart- \\ mouth College.
}

A FEW years ago the fact was forced to our attention that we are living, whether we would want to or not, in one of the climacterics of human history. To us, because we are the custodians of history itself, this looming realization has brought a central responsibility. But the whole shape of it has been slow in emerging.

Recently I have spent some time scanning our professional journals for 1938. They are relatively serene-full of copings, and very earnest copings to be sure, with our perennial problems:

— "Must we be magistrates?"

- "Dare we throw anything away?"

Over the horizon there was a far-off glint of books afire, and we noted it with anger. But our concern appears to have stemmed from, and to have stopped with, an assumption that we could keep civilization intact by keeping the RECORDS of civilization intact. We were technicians, devoted to an exacting technology which took up all our time. Men and women who were in love with freedom lay dying in Spain and China. So far as our professional literature for 1938 reveals to a quick inspection, we did not see the close connection between those tragic happenings and our own presumed right to practice our profession in peace, for the sake of peace.

1 Paper presented at the meeting of the Reference Librarians Section, A.C.R.L., June 18, 1948, Atlantic City, N.J.

\section{Someone Has Called Such People "The Irresponsibles."}

A few months later, the issue broke upon us in purely professional terms. The man who called such people the irresponsibles was nominated to fill the most important library office in the world.

- The controversy consequent upon that appointment is one which most librarians have been happy to forget. Many of them, with grace and magnanimity, have made public occasions for admitting that they acted unwisely in the heat of it. But I am not sure that it should be forgotten, not at least until it has been fully understood. It was the cry of an outraged, righteous professionalism against an apparent, ruthless insult to its own high standards of competence, which had to be defended in the public interest. Over these bitter objections, the episode produced, as most of us are now willing to admit, a perceptive and resourceful $\mathrm{Li}$ brarian of Congress: one who carried still further forward, with high competence, the remarkable work of his predecessor.

Now, this does not add up. Were those who objected so loudly wrong in their prejudgment of the man, or in their concept of their own standards? The answer of "Yes," to the first part of the question, while true, is insufficient. The explanation calls for an answer of "Yes" to the second part of the question as well. Our concept of professionalism current ten years ago or so, was wrong, but only insofar as it is wrong to be inadequate. What we positively believed was itself right and good, but our negative 
attitudes in some measure canceled that virtue.

The opposition to Mr. MacLeish deliberately drew the issue as between the technician and the humanist. I ought in honesty to tell you that I thought it a false issue then, and am even more convinced of it now. Such a controversy, with such an outcome, is merely absurd when reduced to a basis of either technology or humanism. It was not a valid question with $\mathrm{Mr}$. MacLeish. It is not a valid question in the case of any of us, whether a librarian should be a technician or a humanist. These are not alternative values, one of which can do in place of the other.

A technician who has none of the attributes of humanism can be a professional librarian, at a certain level of usefulness, if given adequate direction. But a humanist who has none of the technical skills of our profession cannot be a librarian at all. That does not prevent him from being a very good humanist indeed, provided he gets the kind of help that all of you are frequently called upon to give him.

The fundamental issue, then, was unclear as it was stated. I think we have important reasons for being very clear about it now.

Let us carry the problem a little further. Even though a pure technician, unlike a pure humanist, can be a useful librarian at a certain level, no one has a basis for seeking eminence in this profession if he is content to excel in either of these fields while he really neglects the other. Yet that, I believe, was what was happening in our profession as a whole, ten years ago. Technical competence was regarded as a sufficient goal by far too many of us. We were deluded by the inadequate notion that, just because something is indispensable, it is also enough.

Technical competence by itself was not enough for the world of 1938 . It is even more inadequate today. It is the task of the technician to keep books and their contents in a state of ready availability, granted all the complex procedures, including those of the reference desk, which add up to that simple statement. It is the duty of the humanist to select books with wisdom, and to put them to good uses. That plain statement, too, implies many detailed operations, including those of the reference desk.

\section{Need for Humanism}

Under the impact of Great Issues, the need for humanism has become overwhelmingly important in one field of library work - reference. Among many others, there is one particular reason for this. More than any other of our specialists, the reference librarian deals with people who think they know what they want. Perhaps that will call up a horse laugh or two, from the back benchers. I cannot claim to have sat long enough at a reference desk to make a respectable refutation of long-tested convictions to the contrary. But the typical, if not the average reference question came to me from someone who wanted to make a case-not, alas, for what is true-but for what he believed to begin with.

There is always the woman who believes she is descended from Charlemagne. A passion for objective truth is not likely to be the motive driving her to this little job of relatively harmless research. But once I had to deal with a little man who, as it finally turned out, was writing a treatise to prove that negroes could be "educated" only in proportion to the amount of white blood they contained. I thought back, when I had disposed of him, to the reference librarians in Vienna, Munich, Berlin, who surely had been asked to contribute to the shaping of a number of infamous compositions that sent torture, depravity and death across the world.

Is it part of our task to help crackpots 
and sadists to write vicious books?

The answer, as I see it, is, "Yes, BUT. ..."

"Yes," because I know of no way to deal with evil before it exists. Our task, very strictly, is not to destroy books, not even bad books aborning.

"BUT," because if you believe this, as I do, we cannot shrug off the consequences. If you believe, as I do, that the human intellect cannot keep freedom unless every human intellect is completely free, then we undertake a terrible responsibility. We are confronting again the great issue so brilliantly argued in Areopagitica. No utterance is to be prohibited in advance, but he who utters it is to be completely responsible, before the existing law, for the results of his conduct. Milton did not invent the principle. Socrates argued both ends of it separately, in a pair of famous orations. Copies of these might well be symbolically placed on the two outer corners of every reference desk.

The question I asked a few moments ago is only a part of the basic question: Shall free inquiry continue to exist? Note that that is an absolute question. As soon as you make it relative you have killed the question itself.

Even if we had the skill, I do not believe we have the right to judge the intentions of those who call upon our services. But we still have the right to be ourselves, to be creative rather than passive in our functions. We are more than easy indexes, animated Reader's Guides. We can ask the inquirer to justify his request somewhat, and then make an effort to give him evidence balanced on both sides of the issue. Where we see probable error, we can call it to his attention.

Most of all, I think we are under no obligation to hide our opinions, especially since they may shape importantly the selec- tions we make of materials for others to use -wisely, we hope.

How then are we to select? We can use the machinery of our trade, and it would be egregious of me to attempt to tell you anything about that. But however we may strive to perfect our skill in burrowing by the quickest route to the farthest fact, we shall still have improved only the machinery. If we are to be responsible for the results of our conduct-and I know no reason why reference librarians should be excused from that common obligation of mankind-we cannot neglect a broadening and deepening of our moral perception of the issues which make our times an intense climacteric, perhaps the grand climacteric, of human history.

\section{Great Issues}

That, to my mind, is much the most important of "The Reference Problems Presented by Public Interest in Current Issues."

The chairman of this section, in his original invitation, referred to "great issues" as well as to "current issues," and I am going to stick to the graver implications of the former phrase. It is part of my assignment to tell you something about the particular reference problems that have emerged during our planning for, and our first year of teaching, the Great Issues Course which all regular seniors at Dartmouth College now are required to take.

It gives me some satisfaction to remember that this notable experiment in education really began in our library. John Sloan Dickey, shortly after he assumed the presidency of the college in the fall of 1945, expressed an interest in developing the library service for making evident and available the chief sorts of "public information resources." Our plans for a special center in which to do so were well under way when the idea developed into the course which 
carries the following description in the Dartmouth College Catalogue:

\section{Great Issues}

"This course will relate undergraduate education to the responsibilities of adult living. The lectures and discussions will present issues confronting the public-minded man who is concerned with the maintenance of a just peace, the building of a sound economic order, and the search for values which will enable our culture to survive.

"Instruction in the use and analysis of public information will be included. ..."

Two years ago, when the planning of the course began, it was recognized that library functions were centrally involved, and that our library was neither staffed nor equipped to provide advantageously the particular services that would be needed. The first problem presented, then, was one of libraryfaculty policy. Should this unusual course be served like any other, by our regular staff, with suitable adaptations? Or should we create a special service for the 600 students in Great Issues exclusively? An assistant librarian, assigned to the steering committee of the course, worked out an initial compromise. The Reserve Desk would be used for required readings in the normal fashion. The Reference Department would be called upon for the miscellaneous unpredictable items that are its standard problem. But there would be a separate Public Affairs Laboratory in which to concentrate special or duplicate materials for which the demand could be confidently foreseen.

In this laboratory, any artificial distinctions which may elsewhere be thought to exist between librarianship and teaching faded away. The assistant librarian in charge had argued urgently the course's need for a genuine reference librarian and for a good library housekeeper with training in a periodical or serials department. His five faculty colleagues on the planning com- mittee seemed not to be quite sure what he meant by "housekeeper," and his plea for a reference librarian must have been insufficiently eloquent. As a result, in the fulness of time, his colleagues got their come-uppance. Standing tricks in the P.A.L., as all of them valiantly did on a rotating schedule in the afternoons and evenings, they discovered that they were expected to be reference librarians, and that they often had to be housekeepers in order to find the necessary materials.

Perhaps it was all for the best. If librarians will come as far toward an understanding of the teacher's difficulties as these men came toward a comprehension of reference problems, our common educational enterprise will benefit greatly.

Somewhat to compensate, the assistant librarian, on halftime assignment as director of the Public Affairs Laboratory, found himself confronted alternately by questions calling for the skills of the reference librarian and the teacher. His efforts to cope with both added up to a chastening and useful experience.

Leaving apart the many standard if miscellaneous requests for information which might have come to any reference desk, there are some special or continuing problems which were related to the nature of the work of the Great Issues Course. The consistent "textbook" throughout the year was a national newspaper. Students had their choice of the New York Herald Tribune or the New York Times, and were held responsible, on midsemester and final examinations, for a reasonable knowledge of the important news. In the first semester, each man also had to make a critical study of the handling of a particular news topic over a two-week period, by a variety of newspapers including The $W$ all Street Journal, The Daily $W$ orker, The $W$ ashington Post, The Chicago Daily Tribune, The 
Christian Science Monitor, and others. A frequent difficulty arose from the fact that the Times Index is based upon the final late city edition, while we for our own daily reading in Hanover are forced to rely upon the first edition. A reference department, in this situation, needs both, even before the index and the bound volumes come in.

We greeted the semi-monthly form of the Times Index with uneasy rapture. Our copies of the monthly edition of 1947 had required an average of 46 days to reach us, after the last date indexed. The more frequent issues, so far, have been turning up in about 30 days. Since the median date of each issue under the new system is advanced a week, the time lag has been cut just in half. On the other hand, we are this morning confronted by 2 I separate parts to search for an item that may have occurred at any time since the last yearly volume. We usually can concentrate on a probable date and work both ways. But that is not true of some of the reference questions arising from the Great Issues second semester project, a study of special interest (or "pressure") groups. Has the American Farm Bureau Federation taken a position on any of the evolving versions of the Wagner-Murray-Dingell Bill? We had a multitude of variants of that question to deal with, in connection with 37 such organizations. Often it required the handling of 18 or 20 index parts to come up with a confident negative answer, "No, no stand has been taken."

Cannot we promote some sort of amicable wedding of the New York Times and the H. W. Wilson Company, so that this tremendously important tool can be cumulated perhaps on a quarterly basis?

Of course there are other positive approaches to such questions. The Congressional Quarterly reliably indexes the stands taken by many of the special interest groups at congressional hearings. Facts on File picks up a fair number in addition which represent indirect pressure through general publicity. But both the students writing these term papers and the teachers correcting them needed the negative answers, indicating that a stand was consciously evaded or considered irrelevant.

Another tough problem arising from this project was the membership, actual or claimed, of such special interest groups. The World Almanac's section on "Associations and Societies in the United States" was helpful in most instances. The Britannica Year Book provided more data about fewer groups. Such books as George Seldes' 1 , ooo Americans gave us unfriendly estimates of the size and resources of some groups which were secretive or obviously mendacious about themselves, but it is only by luck that such a compilation is sufficiently recent to be useful.

We had other troubles. For example, our standard practice of destroying unenacted bills at the end of a congressional session has had to be reëxamined. The persistent, unenacted bill is often a symbol of a great issue in itself. The record of its changes, from session to session, can be very significant.

In planning the Reference Collection for the Public Affairs Laboratory, we took a chance on Keesing's Contemporary Archives, a fairly expensive British item, and are glad that we did. The parts and indexes reached us almost as promptly by air as did those of Facts on File. Keesing's not only puts its emphasis more on the international scene, but it has a different method, covering the news in brief and well-organized essays with adequate indexing under national headings.

Instances could be multiplied. These are perhaps typical of the particular problems arising in the Great Issues Course. There 
was one general library issue underlying all the others. We suspected that the average Dartmouth senior did not know how to use his library with intelligent economy of time and effort. Our suspicions were confirmed. We had to face the evidence that most undergraduates entering the last phase of their college experience did not have even the minimum knowledge of the tools and techniques of reference which we had tried to give them for the uses of their freshman year. I have talked about the Times Index. Most of them did not know that it existed. Not one, of the scores whom I directed to it, was aware that it could be used as a key to other newspapers as well. Most of them knew something about the chief periodical indexes, but few had any comprehension of the various possible approaches to the same fact. Awareness of biographical resources began and ended for the great majority with Who's Who. These are confident, if embarrassing, statements. I make them bluntly because it did not take many hours of helping men with their first semester project to discover that a mere reference to the logical source of information was inadequate. Thereafter, in most cases I quizzed the inquirer to see whether he knew how to use the tool to which I was referring him. Usually he had not even heard of it before.

The further embarrassing question arises. What had our Reference Department been doing for these seniors, for three years? The answer, perhaps, is "Too much." It is one of our occupational hazards that we generally can find an answer much more quickly than we can show someone else how it is to be found. Pressed for time, we are likely to do it that way. But in so doing, we are evading the central problem of the librarian as teacher. If the top administrators of colleges do not realize how frequently this problem of choice constrains us, it may be because we have licked our wounds in silence too long. I suggest two answers: (I) An increased recognition of the teaching function of the Reference Desk, with provision of adequately trained personnel. (2) A genuine required course, at an early point in the curriculum, to teach the basic disciplines of research.

Up to this point I have been dealing with a number of issues, varying in size. But my topic is Great Issues. We shall not fully have faced the consequent reference problems until we have decided what it is that makes any current issue merit the adjective "Great." I share the conviction of my colleagues on the Steering Committee, and of most of the 600 students enrolled in the Great Issues Course, that Archibald MacLeish has produced the most thoughtful answers to that question.

At the usual risk of distortion, when the forked roots of quotation are hauled shrieking from their soil of context, I want to give you some of Mr. MacLeish's apt phrases on the subject. They are taken from his lecture "What Is a Great Issue?" which opened the course last fall.

"There is no such thing as $a$ great issue. There are simply issues which at a given time and under given circumstances and to a given society, or more precisely to the individuals who compose a given society, become great issues in the sense of becoming critical and urgent demanding solution. ... They are problems which exist, and can exist, only in the minds of living menwhich is to say in the minds of individual living men. ... An issue ... is the nub, the heart, the crux of a situation in the external world which demands the exercise of judgment and the application of choice...."

Summing up on a later occasion, Mr. MacLeish said, in effect, that every great issue has: (I) Historical depth, (2) Present $\uparrow$ form, (3) Future projection, with a moral core. 
I do not suppose that merely current issues present any very unusual problems. But the factors of historical depth, future projection, and particularly, moral core, do bring upon us, in this profession, the acute and central responsibility which I referred to at the outset.

If we accept these definitions, I think it follows that no great issue can be a new issue, even though the factor of its greatness often is recent. Putting the emphasis upon the other side of the phrase, we can say that no issue is great if it seems to be subject to an early and final solution. To dispose of it completely would be to deny it "future projection."

Both of these points are important because (to put together two parts of Mr. MacLeish's argument) they imply that situations "in the external world" become great issues, with emphasis on the great, only if they urgently exemplify one or more of the deep continuous problems, which is to say the moral problems, of human existence.

Atomic energy has a superficial look of newness about it. But the moment we begin to deal with it as an issue, we ourselves are chin-deep in problems of historical depth, as well as of future projection. We cannot suddenly destroy, once and for all, what has so suddenly burst upon us. There is no clear point at which we can draw the line and say, here nuclear physics and chemistry began. These developments are implicit in the whole past of scientific inquiry, and could come out of it quite independently again, beginning anywhere. If we destroyed all the men and women who have been involved in this perilous business, and all their writings - even if we legislated and posted guards against any renewal of their kind of endeavor-these very measures would project the issue, as an issue, into the future indefinitely.

The problems arising out of the develop- ment of atomic energy are no different, in their essence, from the problems arising out of the development of the stone ax.

If my neighbor learns of this, will he use it to build a better house, or the better to split my skull?

Is it safer for me to tell him what I know, and hope for gratitude, or shall I hide it, and risk his envious hate?

These are problems deep in the moral nature of man. As such, they must have both historical depth and future projection. Any external development may give them present form and high urgency, demanding solution. But the solution is pointless if it ignores the basic factors in human morality.

Just what has this to do with the reference problems of our Great Issues program? It brings us once more to the central issue, which every human individual, and particularly every technical expert, and therefore every reference librarian, must face: the problem of putting knowledge to good use. Here is the basic question: Are you content to make your special learning, your expert technical skill available to any user, no matter what his motives may be?

My own answer to that question again is, "Yes, BUT_-"

And the BUT concerns itself with the echo of a tragic Biblical phrase, "Forgive them, for they know not what they do." I do not believe that we, in the library profession, certainly not those of us who are practicing the technology of reference, can expect forgiveness on any such basis. It is our business to know what we do, to know it well, and to do it with much more, not less, than the average private citizen's moral responsibility. We must not neglect or belittle our technology. It is indispensable, but it is a means, not an end. The aim of our endeavor is the wise use of the riches we unlock. To that end we should have a deepened humanism as our goal. 